\title{
På vej mod en kritisk bibliometri
}

\section{Anmeldelse af Birger Hjørland}

Svend Bruhns (2010). Citationsindexering. Romdrup: Bibliographica.

Svend Bruhns er en rigtig forsker forstået som en person, der forsker fordi forskningen interesserer ham, ikke fordi man er nødt til at forske af ydre grunde (en ret sjælden art i Biblioteks- og informationsvidenskab). Det kan bl.a. ses af at hans væsentligste udgivelser er kommet siden han gik på pension. Forfatteren har tidligere bl.a. redigeret et temanummer af Biblioteksarbejde om forskningsevaluering (med bl. a. et særdeles væsentligt bidrag af Per O. Seglen) og den vægtige afhandling Bibliografiens historie i Danmark, 1700 og 1800-tallet (Bruhns 2004). Bruhns var tidligere tilknyttet Biblioteksskolen (der nu hedder Det Informationsvidenskabelige Akademi, IVA) i Ålborg, og det fremgår af bogens kolofon at han stadigvæk har kunnet trække på sine forbindelser på dette sted til illustrationer og grafisk tilrettelæggelse.

I følgeskrivelsen til anmelderne skriver forfatteren "der findes ingen tilsvarende bog på noget nordisk sprog og det er vel nok den mest omfattende bog om citationsindexering i verden.” Begge dele vil jeg stille et spørgsmålstegn ved da vi jo har Kärki \& Kortelainens bog (1998) på svensk og Bellis (2009) vist ikke er mindre omfattende end Bruhns bog.

Birger Hjørland er cand.psych., fil.dr og professor ved Det Informationsvidenskabelige Akademi. bh@iva.dk
Dette giver anledning til en bemærkning om at titlen "citationsindexering" efter min mening er snævrere end bogens emne, der vel dækker en del af bibliometriens område ( $\mathrm{fx}$ vedr. publicering og forskningsevaluering samt citationer på en måde, der rækker langt ud over citationsindexering).

Det er en vægtig bog. 480 tætskrevne sider. Den er opdelt i 22 kapitler samt bibliografi, register m.v. Kapitlerne er disponeret i fem hovedafsnit:
A. Citationsindexering
B. Publicering og produktivitet
C. Referencer og referencestudier
D. Citationsmønstre
E. Citationsteorier og perspektiver

Ét af kapitlerne (kap. 18) er skrevet af Jesper W. Schneider (IVA, afdelingen i Ålborg) og hedder "kortlægning og visualisering af videnskabsområder". Resten af bogen er skrevet af Svend Bruhns selv (registret dog undtaget).

Bogen er udgivet på forfatterens eget forlag. Dette kan give anledning til en kommentar. I den vejledning "Søg og du skal finde" som IVA udgiver står der: "Der er større garanti for bogens kvalitet hvis den er udkommet på et etableret forlag, end hvis den er fra "forfatterens eget forlag"." (Alsted Henrichsen \& Fogh-Nielsen, 2011, side 20). Det er rigtigt, at bogen kunne have vundet ved en forlagsredaktørs gennemgang (Jeg deler i høj grad Burchardts vurdering (2010) at bogen er for løst redigeret). Men jeg 
synes alligevel det er et problematisk råd, som IVAs søgevejledning giver. Bøger udgives i vid udstrækning på eget forlag fordi de er for smalle til kommercielle forlag. Bogen under anmeldelse er den eneste og dermed også indtil videre den bedste introduktion på dansk.

Bogen er spækket med referencer til litteraturen og med introduktioner til og ofte kritisk diskussion af disse referencer. Den er "tung" og måske mere egnet som håndbog end som lærebog eller videnskabelig monografi. Selvom forfatteren ofte kommer med egne vurderinger vil jeg ikke betegne den som en forskningsmonografi. Bogen behandler såvel de tekniske aspekter ved søgning i citationsindexer som de empiriske studier og teoretiske kontroverser inden for bibliometrien. De, fx studerende, der gør sig den ulejlighed at læse bogen vil få et ret bredt grundlag i bibliometriens teori og praksis.

Men Svend Bruhns bog er ikke blot en detaljeret oversigt over forskningen på en del af det bibliometriske område. Jeg har kaldt anmeldelsen på vej mod en kritisk bibliometri, og jeg vil nu forklare, hvad jeg lægger i denne term, og hvordan Bruhns efter min opfattelse bidrager hertil.

Det modsatte af kritisk bibliometri kan man kalde ukritisk bibliometri (eller som Bruhns, 2010, side 278, betegner som at lide af impactitis) (denne term er også benyttet i Bruhns, 2010b, side 31). Ukritisk bibliometri er anvendelse af bibliometriske indikatorer uden hensyntagen til de videnskabelige problemer, der har været rejst (fx Seglens kritik af Journal Impact Factor (JIF) til forskningsevaluering), eller som fx Lindsay (1989) siger: Tendensen til at måle det, der kan måles i stedet for det, der er validt (dvs. gyldigt). Ukritisk bibliometri er en tro på at "tallene taler for sig selv" uden at undersøge de (sociale) mekanismer, der ligger bag givne bibliometriske mønstre. Som Bruhns skriver (2010 side 366) så er der en tendens til at positivister anser deres eget udgangspunkt for videnskabeligt, men modstandernes for uvidenskabelig politisering. Men den kritiske bibliometri er, når den er bedst, stærkt videnskabelig underbygget, så derfor kan og bør argumentet vendes om: Det er positivisterne, der politiserer på en uvidenskabelig måde. Eksempler på kritisk bibliometri med god videnskabelig basis er fx den allerede omtalte kritik af JIF, Bruhns egen kritik af Ingwersens forsvar for anvendelsen af Social Sciences Citation
Index (SSCI) (Bruhns, 2010, side 254-256) og Dam Christensens kritik af anvendelsen af Bradford til materialevalg (Dam Christensen, 2007). Jeg vil da også gerne i denne forbindelse fremhæve min egen og Jeppe Nicolaisens kritik af Bradfords spredningslov (Hjørland \& Nicolaisen, 2005; Nicolaisen \& Hjørland, 2007). Ingen af de tre sidste referencer er dog nævnt i bogen.

Kritisk bibliometri må altså ikke forstås som en afvisning af relevansen af bibliometriske indikatorer, men som et udtryk for at bibliometriske værktøjer ikke kan anvendes mekanisk, men forudsætter viden om underliggende mekanismer, der er ansvarlige for de frembragte mønstre. Sådanne mekanismer er først og fremmest af viden(skabs)sociologisk og videnskabsteoretisk natur. Hvis man fx ikke kender begreber som videnskabelige traditioner, paradigmer og genrer er man dårligt udrustet til at forstå bibliometri (se fx Hjørland, 2002). Uden en sådan viden er man næsten per automatik en "ukritisk" bibliometriker.

Denne anmeldelse kan ikke beskæftige sig med hvert eneste kapitel i bogen. Jeg vil nøjes med at se lidt nærmere på kapitel 20: "Citationsteorier" og kapitel 21: "Reference- og citationsteori". Kapitel 20 er udformet som en konflikt mellem to parter: "citationisterne" og "anticitationisterne". Disse defineres side 365: "En citationist anvender citationsstudier i sin forskning og er positivt indstillet over for værdien af citationsstudier"; "anticitationister, dvs. folk som er skeptiske, eller måske direkte afvisende over for anvendelsen af citationer som indikatorer; Sidste begreb tilskriver Bruhns White $\left(1990^{1}\right)$. Jeg har selv alternativt foreslået at skelne mellem kritiske og ukritiske bibliometrikere: Spørgsmålet er for mig ikke om bibliometriske mønstre udtrykker en form for realitet, men hvad denne realitets beskaffenhed er, hvordan den skal fortolkes. Det er vel ret indlysende at hvis en bestemt forskningsretning af den ene eller anden grund dominerer i en periode, så giver det sig udtryk i citationsmønstre. Men det kan naturligvis ikke tages som et udtryk for at denne retning nødvendigvis er frugtbar. Den kan fx blot være udtryk for et modefænomen eller en "boble".

Der gennemgås en del teorier, men Nicolaisens fremragende oversigt (2007) bruges tilsyneladende ikke (selvom den er medtaget i bogens bibliografi). Bruhns refererer bl.a. den socialkonstruktivistiske citationsteori, men på en skuffende måde. Jeg mener 
vi må skelne mellem den måde socialkonstruktivismen er blevet (mis)forstået af bibliometrikere og den måde socialkonstruktivismen forstås på i videnskabsteori og -sociologi. I den sidstnævnte betydning påvises hvordan sociale forhold påvirker videnskaben, fx hvordan den psykologiske intelligensforskning blev udviklet ud fra militære interesser og skoleadministratorers interesser (men altså ikke underviseres eller undervistes interesser), og at disse interesse former selve den teori, som konstrueres (jf. Danziger, 1997). Det er i mine øjne et synspunkt, der har bidraget positivt til videnskabshistorien (selvom jeg ikke her vil tage stilling til synspunktet i sin helhed). Men i den bibliometriske optik forstås socialkonstruktivisme nærmest som en form for uredelighed, hvor forskere ikke citerer de, der bør citeres, men dem, som man fx gerne vil fedte for eller læne sig op ad. Denne bibliometriske forståelse gør i mine øjne socialkonstruktivismen ret uinteressant. Jeg mener faktisk at en dybere beskæftigelse med videnskabsteorier som socialkonstruktivisme, positivisme, paradigmeteori etc. rummer nøglen til egentlige teorier om citationer. Det er derfor beklageligt at disse er meget overfladisk behandlet i bogen.

Kapitel 20 og 21 bygger på en distinktion mellem begrebet referencer og citationer - og dermed referenceteorier og citationsteorier (som det også fremgår af kapitlernes overskrifter). Jeg vil gerne betvivle frugtbarheden af denne distinktion - selvom den er almindelig i litteraturen. Når jeg i denne anmeldelse refererer til fx Bruhns (2010b), dvs. afgiver en bibliografisk reference til denne artikel, så modtager Bruhns ikke en citation i citationsdatabaserne fordi min anmeldelse er i et tidsskrift (Dansk Biblioteksforskning), der ikke registreres i disse databaser. Men det kan det jo komme til hvis de udvider dækningen (eller hvis jeg citerede samme værk i fx en artikel i Journal of Documentation). Pointen er, at enhver teori om citationer dybest set er en teori om forfatteres referenceadfærd. Det er måske også det, Bruhns når frem til, men det at han omtaler citationsteorier i kap. 20 og så reference- og citationsteorier i kap. 21 er jo at disponere stoffet på grundlag af en problematisk skelnen.

Stilen i bogen er ofte meget "friskfyragtig", fabulerende, uformel og talesprogsagtig. Vi har allerede stødt på eksemplet "at lide af impactitis". Andre eksempler er:
- side 38: "ISI er "for profit" - men bagsiden af guldstykket er at det er næsten umuligt for kapitalisten at erkende at hans produkt ud over de uomtvistelige fordele også har nogle negative sider"; eller

- side 219: "Jamen vi andre ved jo at Watson \& Crick var klare over at der var nobelprispotentiale i DNA-forskning og at de ikke var interesserede i at dele prisen med alt for mange"; eller side

- 380: "Empire strikes back - citationisterne strammer grebet" eller

- side 383: "Det er også som om "anticitationisterne" er blevet trætte af at sende pile mod ISI-templet".

Bogen kunne med fordel have indeholdt et begrebsleksikon, især når der fx afslutningsvis i bogen siges: "Rektor magnificus og de to andre højlærde herre synes i deres brev at sætte lighedstegn mellem bibliometri og "analyse af forskningscitationer", så inden diskussionen går videre er det nok en idé at få klarlagt de grundlæggende begreber” (side 423). Jeg er ikke helt sikker på hvad måde Bruhns mener at de høje herrer har misforstået begreberne. Det ville være en god hjælp om læseren var hjulpet på vej, fx i form af et begrebsleksikon.

Bogen er en omfattende præsentation af litteratur om referencer og citationer og deres anvendelse. Som sagt med tilløb til kritiske analyser og -bidrag. Den er dog meget præget af specifikke bibliometriske undersøgelser og er ret tynd i sin dækning af bredere teorier, der kan belyse baggrunden for de empiriske mønstre. Selvom socialkonstruktivismen er nævnt flere steder er der stadigvæk behov for litteratur, der i højere grad forbinder bibliometrien med videnskabssociologi, videnskabshistorie, videnskabsteori og videnskabelig genreteori. Jeg deler som sagt også Burchardts vurdering (2010) at bogen er lidt løst redigeret. Men det ændrer ikke på det forhold at bogen er en guldgrube af informationer om citationsindexer, citationsanalyse og bibliometri og ofte med afsæt i helt aktuelle kontroverser bl.a. i relation til forskningsevaluering.

PS! Som epigraf har Bruhns valgt følgende: "Naar Skyggen er ligest, da hulke de Små Som stirre derpå!”

Jeg savner - fx på kolofonen - en begrundelse for valget at denne epigraf 


\section{Note}

1. Begrebet "anticitationist" har jeg imidlertid ikke kunnet verificere i White (1990).

\section{Referencer}

Alsted Henrichsen, Lise \& Fogh-Nielsen, Sine (2011). Søg og du skal finde. (2011). 4. udgave. Redaktion af 4. udgave: Lykke Kyllesbech Holm, Birger Larsen og Bodil Christensen. Købehavn: Det Informationsvidenskabelige Akademi. Hentet 201106-19 fra: http://www.iva.dk/soegogduskalfinde

Bellis, Nicola De (2009). Bibliometrics and Citation Analysis: From the Science Citation Index to Cybermetrics. Lanham, Maryland: The Scarecrow Press, Inc.

Bruhns, Svend (2010b). Tidsskrifters impact factor (JIF) er et dårligt surrogat. Magisterbladet \#13, 3031. (Kronik).

Bruhns, Svend (2004). Bibliografiens historie i Danmark, 1700 og 1800-tallet. Aalborg: Aalborg Universitetsforlag.

Bruhns, Svend (red.). (1997). Temanummer om forskningsevaluering. Biblioteksarbejde \#48. Tilgængelig på: http://www.biblioteksarbejde.dk/art/ BA48/48-indhold.htm

Burchardt, Jørgen (2010). Anmeldelse af Svend Bruhns: Citationsindexering. DVR (Danske Videnskabsredaktørers hjemmeside). Hentet 2011-06-19 fra: $\mathrm{http}: / /$ www.videnssamfundet.dk/a.aspx?ItemId=114

Dam Christensen, Hans (2007). Kunsten at vælge fra: Om bradfordsk materialevalg og vidensorganiseringens socialitet. Dansk Biblioteksforskning. 3(1), 31-43. Også tilgængelig 2011-05-05 fra: http://www.danskbiblioteksforskning.dk/2007/nr1/ dam $\% 5$ Fchristensen.pdf
Danziger, Kurt (1997). Naming the mind. How psychology found its language. (Chapter 5: Putting intelligence on the map). London: Sage.

Hjørland, Birger (2002), Epistemology and the Socio-Cognitive Perspective in Information Science. Journal of the American Society for Information Science and Technology, 53(4), 257-270.

Hjørland, Birger \& Nicolaisen, Jeppe (2005). Bradford's Law of Scattering: Ambiguities in the Concept of "Subject". I: Crestani, F. \& Ruthven, I. (Eds.): CoLIS 2005, LNCS 3507. Berlin: SpringerVerlag. (Side 96-106).

Kärki, Riitta \& Kortelainen, Terttu (1998). Introduktion till Bibliometri. Helsingfors: NORDINFO. Findes i fuldtekst på: https://www.abo.fi/student/media/10046/bibliometribok.pdf

Lindsay, D. (1989). Using citation counts as a measure of quality in science: Measuring what's measurable rather than what's valid. Scientometrics, 15(3/4), 189-203.

Nicolaisen, J. (2007). Citation analysis. Annual Review of Information Science and Technology, 41: 609-641

Nicolaisen, Jeppe \& Hjørland, Birger (2007). Practical potentials of Bradford's law: a critical examination of the received view. Journal of Documentation. 63(3), 359-377.

Seglen, Per. O. (1996). ). Bruk av siteringer og tidsskriftimpaktfaktor til forskningsevaluering. Biblioteksarbejde \#48, side 27-34. Hentet 2011-06-19 fra: http://www.biblioteksarbejde.dk/art/BA48/seglen(1996).pdf

White, Howard D. (1990). Perspectives on author cocitation analysis. Introduction. Journal of the American Society for Information Science, 41(6), 430-432. 